\title{
Multiple Primary Lung Carcinomas in the Same Lobe
}

\author{
Aynı Lobda Saptanan Multipl Primer Akciğer Tümörleri
}

Mustafa Akyıl', Mustafa Vayvada' ${ }^{1}$ Elçin Ersöz' ${ }^{1}$, Ayçim Şen², Çağatay Tezel'

\begin{abstract}
Multiple primary lung cancers are unusual but important to identify, since the therapy protocol and the prognosis will be different when compare with metastatic tumors. We present the case of a 64 -year-old man with synchronous lung tumors of different histopathological patterns in the same lobe. Radiological investigation revealed two areas of high-intensity fludeoxyglucose uptake of varying size within the left upper lobe. He underwent left upper lobectomy. Histological analysis confirmed these lesions as adenocarcinoma and moderately differentiated squamous cell carcinoma.
\end{abstract}

Key words: Synchronous tumors, multiple primary cancers, lung.

Multiple primary lung cancers were first defined by Martini and Melamed and described as either synchronous or metachronous (1). A second pulmonary tumor is most likely a metastatic focus, from another source, or the recurrence of a primary tumor; it may also be a secondary primary lung tumor. Since the prognosis and the treatment

\section{Özet}

Multipl primer akciğer kanserleri; nadir görülmelerine rağmen, metastatik akciğer kanserleri ile karşılaşıırıldıklarında, tedavi şeması ve prognozu açısından farklılık gösterecekleri için tanı almaları oldukça önemlidir. Burada, merkezimizde tanı konan, aynı lobda ve farklı histopatolojik tipte senkron tümörleri olan 64 yaşında bir olgu sunulmuştur. Radyolojik çalışmalarda, sol üst lob içerisinde yüksek yoğunluklu fludeoksiglukoz tutulumu olan farklı boyutlarda iki alan saptanmışır. Hastamıza sol üst lobektomi uygulanmıştır. Histopatolojik çalışmalar göstermiştir ki; belirtilen lezyonlardan biri adenokarsinom, diğeri ise orta derecede diferansiye skuamoz hücreli karsinom yapısındadır.

Anahtar Sözcükler: Senkron kanser, multıpl primer kanser, akciğer.
'Department of Thoracic Surgery, Süreyyapaşa Chest Diseases and Thoracic Surgery Training and Research Hospital, İstanbul, Turkey

${ }^{2}$ Department of Pathology, Süreyyapaşa Chest Diseases and Thoracic Surgery Training and Research Hospital, İstanbul, Turkey choices are different, obtaining the correct diagnosis is critical when multiple pulmonary nodules are detected concurrently. In this study we present a case of two histologically different primary tumors in the same lobe treated with a left upper lobectomy. The staging of these tumors were discussed.

Submitted (Başvuru tarihi): 16.1 1.2014 Accepted (Kabul tarihi): 09.02.2015

Correspondence (iletişim): Çağatay Tezel, Department of Thoracic Surgery, Süreyyapaşa Chest Diseases and Thoracic Surgery Training and Investigation Hospital, İstanbul, Turkey

e-mail: mdcagatay@hotmail.com

\author{
'Süreyyapaşa Göğüs Hastalıkları ve Göğüs Cerrahisi Eğitim \\ ve Araştırma Hastanesi, Göğüs Cerrahisi Kliniği, İstanbul \\ 2Süreyyapaşa Göğüs Hastalıkları ve Göğüs Cerrahisi Eğitim \\ ve Araştırma Hastanesi, Patoloji Bölümü, İstanbul
}




\section{CASE}

A 64 -year-old man was admitted with chest pain. A chest radiograph showed opacity in the field of the left upper lung (Figure 1). Thorax computed tomography showed a lesion in left the upper lobe (Figure 2). Preoperative flexible bronchoscopic examination showed no endobronchial lesion and the cytology of bronchial lavage was not diagnostic. Positron emission tomography scanning revealed two areas of high-intensity fludeoxyglucose (FDG) uptake: $33 \times 28 \mathrm{~mm}$ in anterior segment of the left upper lobe (SUVmax of 14.3) and $25 \times 17 \mathrm{~mm}$ in the apicoposterior segment (SUVmax of 11.9) (Figure 3). There was also associated low-intensity FDG uptake mediastinal mass (SUVmax of 3.4) and subcentimeter mediastinal lymph node (SUVmax of 3.2). There was no other focus of FDG uptake in the abdominopelvic organs, lymph chains, or peritoneal and serosal surfaces. Skeletal system and intracranial structures did not show any FDG uptake either. Respiratory function tests as forced vital capacity was $3.49 \mathrm{~L}(96 \%)$ and forced expiratory volume in first second was $2.84 \mathrm{~L}(100 \%)$.

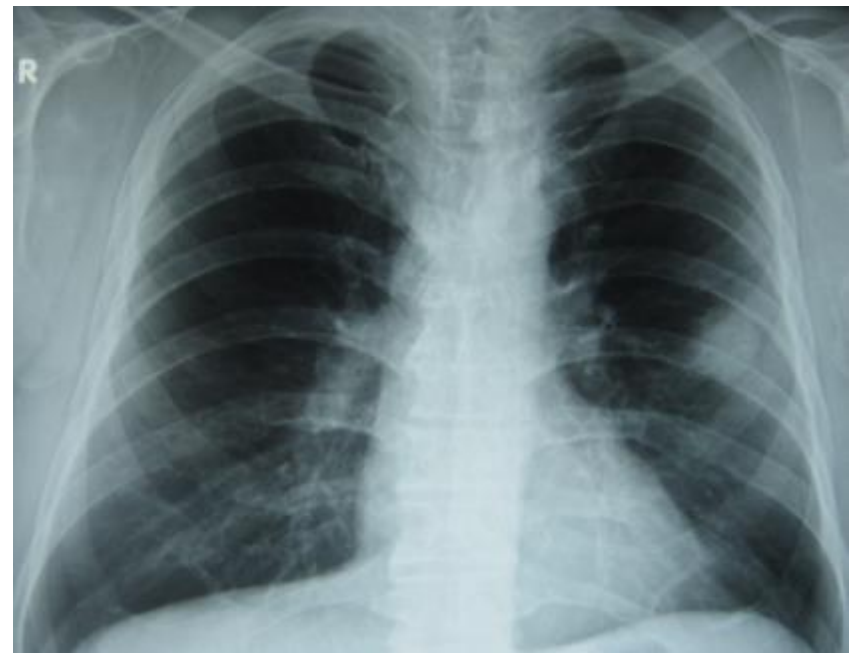

Figure 1: Chest radiograph at presentation

Principally we sampled number \#2R, \#2L, \#4R, \#4L, and \#7 lymph nodes using mediastinoscopy. In frozensections the stations were reported as negative. Then left a thoracotomy was performed, and sampled the lesion in the anterior segment. Histological analysis of the resected lung tissue revealed malignant features in the frozen section. A left upper lobectomy and a systemic lymph nodes dissection were performed. Histopathological examination of the lesion in the anterior segment was reported as adenocarcinoma whereas the tumor in the apicoposterior segment was reported as moderately differentiated squamous cell carcinoma (Figure $4 a$ and b). Resection margins were negative. The pathologic exami- nation showed no nodal involvement of adenocarcinoma that tumor was evaluated as stage $1 \mathrm{~A}$ and $\mathrm{Tl} \mathrm{b}, \mathrm{NO}, \mathrm{MO}$ according to the TNM staging of lung cancer (2). Since the hilar lymph node was confirmed to be metastasis from squamous cell carcinoma, it was staged as $2 \mathrm{~A}$ and $\mathrm{T} 2 \mathrm{a}$, $\mathrm{Nl}$, MO. The drains were taken out on postoperative day three and the patient was discharged on the fourth day, planning adjuvant chemotherapy.

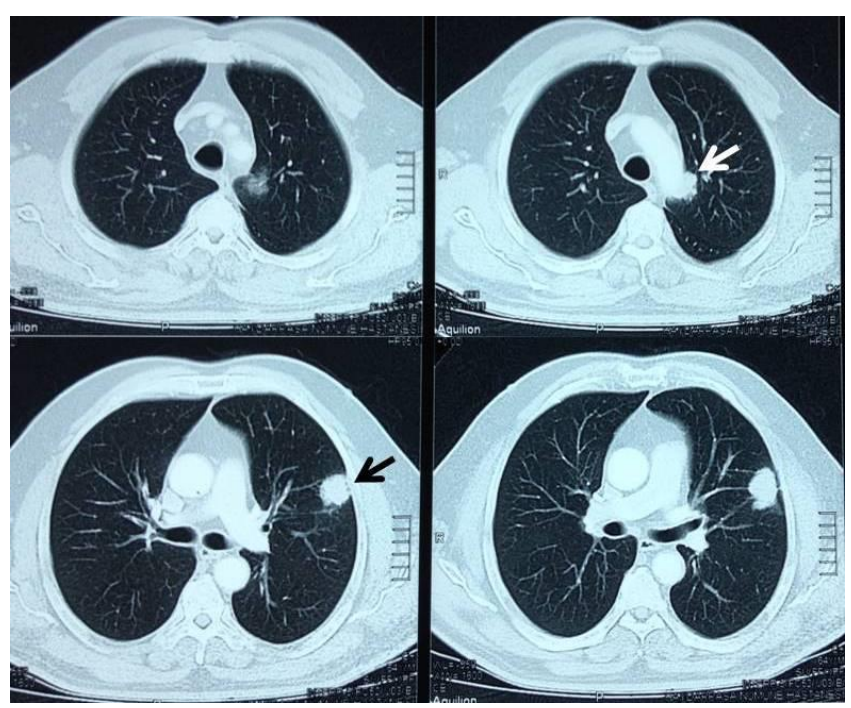

Figure 2: Thorax computed tomography demonstrating two tumors in the left upper lobe. The white arrow depicts the central tumor and the black arrow depicts the peripheral tumor

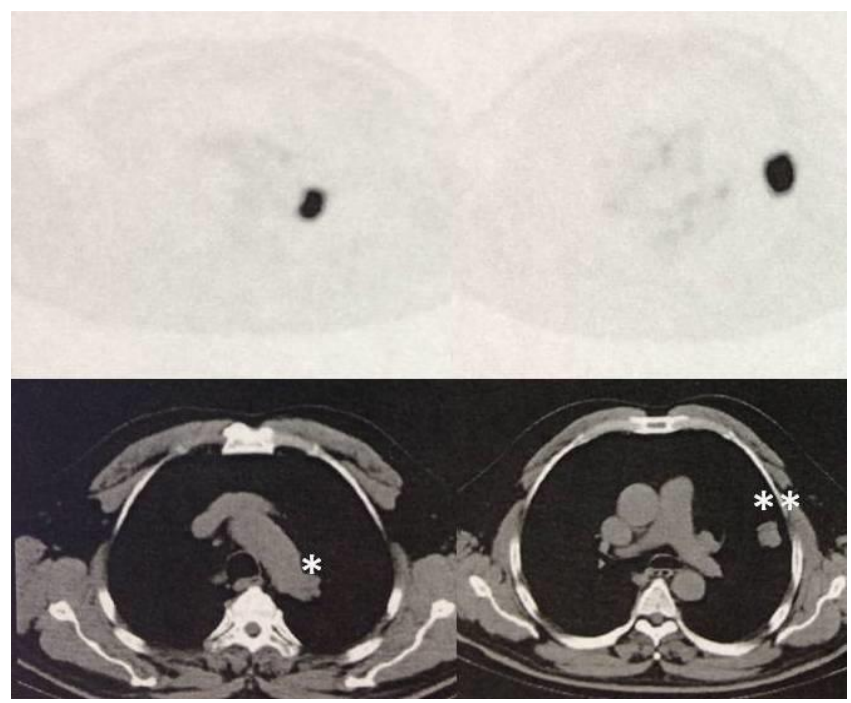

Figure 3: PET/CT images demonstrating the presence of two highintensity FDG uptake areas in the left upper lobe

\section{DISCUSSION}

When two pulmonary tumors are seen simultaneously, the possibility of synchronous tumors should be taken into account. Synchronous tumors are the tumors identified concurrently in patients with multiple primary lung cancers. If there has been a time interval of more than 12 months 
between the detection of the first lesion and the detection of a subsequent lesion, the lesions are identified as metachronous tumors. Five-year survival is reported to be $28 \%$ and $37.5 \%$ when the lesion is surgically removable $(1,3)$.

Synchronous tumors may be diagnosed according to the criteria originally proposed by Martini and Melamed (1), and which are based on characteristics of the tumor (inclusive of, but not limited to, location, morphology, vascular invasion, metastasis, presence or absence of carcinoma in situ). Today, the accepted diagnostic criteria include, the demonstration of synchronous masses with different histology, and at histologically similarity, arousal of distinct and separate endobronchial foci of the tumors $(4,5)$.

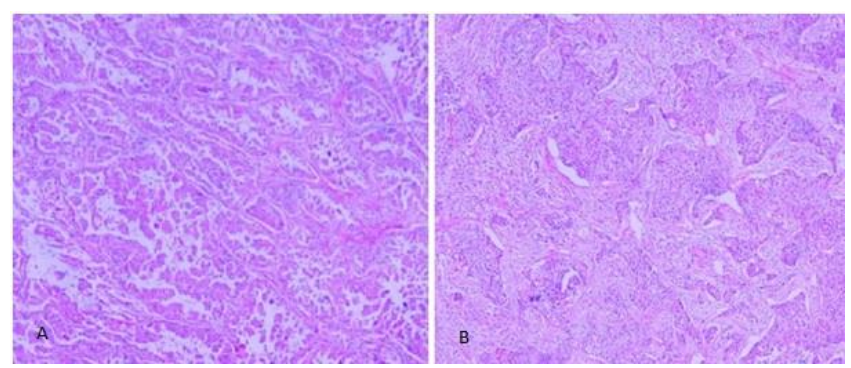

Figure 4a, b: Formalin-fixed paraffin-embedded (FF-PE) samples, right (A) adenocarcinoma and the left (B) squamous cell carcinoma (HE, 10X)

In our case, two primary tumors were simultaneously identified in the same lobe. These tumors, having different histopathological patterns, are taken as criteria defining synchronous tumors.

According to the literature, multiple primary lung cancer occurs with an incidence of $1 \%$ to $16 \%$ in clinical series (6-8). Autopsy studies have revealed a higher incidence of $3.5 \%$ to $14 \%$ (9). Antakli et al. (10) demonstrated a $4.1 \%$ incidence of the second primary lung cancer in 1,572 cases of cancer patients: the metachronous cancer comprising $60 \%$ and the synchronous $40 \%$.

Squamous carcinoma is the most common histopathological type in multiple primary lung cancers. Most of the cases contain associations between squamous carcinoma and one of other tumor types. Squamous carcinoma squamous carcinoma, squamous carcinoma - small cell carcinoma, squamous carcinoma - adenocarcinoma associations are the most frequent pathologic associations in synchronous tumors $(11,12)$. In our case, adenocarcinoma was detected in the anterior segment and moderately differentiated squamous cell carcinoma was detected in apicoposterior segment of the left lung.

Surgical strategy in patients with metachronous and synchronous lung carcinomas is determined on the basis of patient status and tumor resectability (7). In 2010, Finley et al. (13) reported a series of 175 patients with synchronous primary lung cancers who had undergone surgical resections, where it was discovered that, in $15 \%$ of them, the lesions were in the same lobe. Patients with synchronous tumors, five-year survival has been determined as $27 \%$ in patients undergoing pneumonectomy and $71 \%$ after lobectomy / segmentectomy (14). In the case of our patient, a left upper lobectomy was performed. Long-term survival has been reported to be better in patients with synchronous tumors than the patients with stage $3 \mathrm{~B}$ and stage 4 pulmonary cancers (15).

The seventh revision of the International Association for the Study of Lung Cancer (IASLC) tumor-node-metastasis (TNM) staging of lung cancer led to alterations in the classification of the $T$ and $M$ descriptors of the staging system. T4 tumors with additional nodule(s) in the same lobe of the primary tumor have been reclassified as T3 (2). In 2012, Sepehripour et al. (16) presented a case with three synchronous, histologically different, primary tumors in the same lobe and the reclassification of TNM staging has led to the downstaging of the tumor, allowing consideration for surgical management, in this patient.

According to the seventh revision of the IASCL TNM staging of lung cancer, multiple primary tumors should be separately staged (2). In our case, according to TNM staging system, one of the tumors was evaluated at stage $1 \mathrm{~A}$ and $\mathrm{T} 1 \mathrm{~b}, \mathrm{NO}, \mathrm{MO}$, while the other tumor was revealed to be at stage $2 \mathrm{~A}$ and $\mathrm{T} 2 \mathrm{a}, \mathrm{N} 1, \mathrm{MO}$. Therefore, the presence of nodal involvement (either N1 or N2), especially along with other poor prognostic predictors, indicates an aggressive clinical course and consideration should be first given to other available curative treatment options (17). In our case adjuvant chemotherapy was planned.

In conclusion, the possibility of detecting synchronous tumors should be considered, if more than one pulmonary tumor is seen simultaneously. We believe that the diagnosis is important because of the changes in staging, prognosis and treatment modalities.

\section{CONFLICTS OF INTEREST}

None declared.

\section{AUTHOR CONTRIBUTIONS}

Concept - M.A., M.V., E.E., A.Ş., Ç.T.; Planning and Design - M.A., M.V., E.E., A.Ş., Ç.T.; Supervision - M.A., M.V., E.E., A.Ş., Ç.T.; Funding - A.Ş.; Materials - M.V.; Data Collection and/or Processing - M.A.; Analysis 
and/or Interpretation - A.S. ; Literature Review - E.E.; Writing - M.A.; Critical Review - C.T.

\section{YAZAR KATKILARI}

Fikir - M.A., M.V., E.E., A.Ş., Ç.T.; Tasarım ve Dizayn M.A., M.V., E.E., A.Ş., Ç.T.; Denetleme - M.A., M.V., E.E., A.Ş., Ç.T.; Kaynaklar - A.Ş.; Malzemeler - M.V.; Veri Toplama ve/veya İşleme - M.A.; Analiz ve/veya Yorum A.Ş.; Literatür Taraması - E.E.; Yazıyı Yazan - M.A.; Eleştirel Inceleme - C.T.

\section{REFERENCES}

1. Martini N, Melamed MR. Multiple primary lung cancers. J Thorac Cardiovasc Surg 1975; 70:606-12.

2. Rami-Porta R, Ball D, Crowley J, Giroux DJ, Jett J, Travis WD, et al. The IASLC Lung Cancer Staging Project: proposals for the revision of the $T$ descriptors in the forthcoming (seventh) edition of the TNM classification for lung cancer. J Thorac Oncol 2007; 2:593-602.

3. Tanimura S, Kajita M, Tsuchiya R, Miyazawa N, Naruke T, Yoneyama $T$, et al. Diagnosis, treatment and prognosis of multiple primary carcinoma of lung. Haigan 1982; 22:45-52

4. Ferguson MK. Synchronous primary lung cancers. Chest 1993; 103(4 Suppl):398S-400S. [CrossRef]

5. Yoon HJ, Lee HY, Han J, Choi YL. Synchronous triple primary lung cancers: a case report. Korean J Radiol $2014 ; 15: 646-50$. [CrossRef]

6. Ferguson MK, DeMeester TR, DesLauriers J, Little AG, Piraux M, Golomb H. Diagnosis and management of synchronous lung cancers. J Thorac Cardiovasc Surg 1985; 89:378-85.

7. Flynn MJ, Doris R, Shahira AE, Higgins B, Barnard S. Metachronous and synchronous lung tumors: five malignant lung pathologies in 1 patient during 7 years. Ann Thorac Surg 2004; 78:2154-5. [CrossRef]

8. Shen $C, X \cup H$, Liu L, Zhou $Y$, Chen D, Du $H$, et al.
"Unique trend" and "contradictory trend" in discrimination of primary synchronous lung cancer and metastatic lung cancer. BMC Cancer 2013; 13:467. [CrossRef]

9. Mathisen DJ, Jensik RJ, Faber LP, Kittle FK. Survival following resection for second and third primary lung cancers. J Thorac Cardiovasc Surg 1984; 88:502-10.

10. Antakli T, Schaefer RF, Rutherford JE, Reed RC. Second primary lung cancer. Ann Thorac Surg 1995; 59:863-6. [CrossRef]

11. Bower SL, Choplin RH, Muss HB. Multiple primary bronchogenic carcinomas of the lung. Am J Radiol 1983; 140:253-8. [CrossRef]

12. Kobashi Y, Fukuda M, Yoshida K, Miyashita N, Niki Y, Oka M. Synchronus presentation of early-stage small cell carcinoma and adenocarcinoma in the same lung lobe. Intern Med 2006; 45:287-91.

13. Finley DJ, Yoshizawa A, Travis W, Zhou Q, Seshan VE, Bains MS, et al. Predictors of outcomes after surgical treatment of synchronous primary lung cancers. J Thorac Oncol 2010; 5:197-205. [CrossRef]

14. Kocaturk Cl, Gunluoglu MZ, Cansever L, Demir A, Cinar $U$, Dincer $\mathrm{SI}$, et al. Survival and prognostic factors in surgically resected synchronous multiple primary lung cancers. Eur J Cardiothorac Surg 2011; 39:160-6. [CrossRef]

15. Battafarano RJ, Meyers BF, Guthrie TJ, Cooper JD, Patterson GA. Surgical resection of multifocal non-small cell lung cancer is associated with prolonged survival. Ann Thorac Surg 2002; 74:988-93. [CrossRef]

16. Sepehripour AH, Nasir A, Shah R. Multiple synchronous primary tumours in a single lobe. Interact Cardivoasc Thorac Surg 2012; 14:340-1. [CrossRef]

17. Tanvetyanon $T$, Finley DJ, Fabian $T$, Riquet $M$, Voltolini $L$, Kocaturk $C$, et al. Prognostic factors for survival after complete resections of synchronous lung cancers in multiple lobes: pooled analysis based on individual patient data. Ann Oncol 2013; 24:889-94. [CrossRef] 